\title{
REVIEW \\ Public health strategy against overweight and obesity in Mexico's National Agreement for Nutritional Health
}

\author{
L Latnovic and L Rodriguez Cabrera
}

Overweight and obesity are major world global health challenges of the 21 st century. Mexico is not an exception. Approximately $70 \%$ of the adult Mexican population has an excessive body weight. The prevalence of obesity and overweight in Mexican school children aged 5-11 is also high: one child in four is overweight. In light of the seriousness of the situation, the solutions for this problem are based on modification of the environments and change of individual habits and behaviors related to nutrition and physical activity. As a result, the Mexican government, public sector and academy established three common goals and 10 priority objectives that are expressed in the National Agreement for Nutritional Health-Strategy to Control Overweight and Obesity. The obesity problem requires interventions and policies that reside outside of the health sector domain, key aspects of this public health policy was agreement among all stakeholders on cross-cutting actions. The best examples of National Agreement's inter-sectorial action implementation is in the school setting and Code of 'Self Regulation' on Advertising of Food and Non-Alcoholic Beverages to Children introduced by the food and beverage industry. The ultimate goal of this national policy is to provide the strategic plan for healthy weight and better health, by promoting healthy lifestyles focused on correct diet and physical activity in all life stages, from pregnancy and early childhood and on into adulthood by a multi stakeholder approach. Although there have been great achievements in some areas of implementation, there are still challenges to confront.

International Journal of Obesity Supplements (2013) 3, S12-S14; doi:10.1038/ijosup.2013.5

Keywords: overweight; nutrition; health policy; inter-sectorial action

Overweight and obesity are major world global health challenges of the 21 st century. Developed as well as low- and middle-income countries are dealing with the new pandemic of obesity and its accompanying non-communicable chronic diseases.

Mexico is not an exception. According to the Organization for Economic Co-operation and Development, ${ }^{1}$ our country has the second most obese population in the world. On the basis of the last National Survey on Health and Nutrition, ${ }^{2} 39.5 \%$ of Mexican men and women were overweight and $31.7 \%$ obese. Approximately $70 \%$ of the adult Mexican population has an excessive body weight and is in potential danger of developing diabetes, coronary and heart disease, high blood pressure, high cholesterol, some cancers, among other chronic health problems. Obesity is responsible for about $8-10 \%$ of premature deaths in Mexico. ${ }^{3}$

The prevalence of obesity and overweight in Mexican school children aged $5-11$ is also high: $25 \%$ of children are overweight. ${ }^{2}$ Compared with data from the National Nutritional Survey from $1999{ }^{4}$ in just a period of 7 years, the increase was 39.7 in both sexes.

The prevalence in the adolescent population (12-17 years old) is also growing at an alarming rate, as has been documented in national surveys conducted in 1988, 1999 and $2006 .^{5}$

In addition to the health burden posed by obesity, it also poses a great threat to the country's public finances. The cost created by this disease accounts for $0.2 \%$ of the gross domestic product and $9 \%$ of the total expenditure on health. In 2008 alone, the indirect cost affected $\sim 45500$ families, meaning that they were facing economic debt and impoverishment due to health-related issues. ${ }^{5}$
Obesity and other non-communicable chronic diseases have multifactorial causes and are contributed to by an obesogenic environment. In the last few decades, Mexico has experienced abrupt modifications in lifestyle, and some practices such as exclusive breastfeeding for the first 6 months of life, general diet and eating habits have changed. Urbanization, economic growth, higher life expectancy, integration of women into the labor force and greater availability of industrialized products as well as more sedentary lifestyle are some of the key factors responsible for this change (Figure 1).

There has been great transformation in food consumption patterns. According to the National Survey on Income and Expenditure in households, ${ }^{6}$ during a 14-year period (1984-1998) there was a decrease in fruit and vegetable purchase by $29.3 \%$ and an increase of $37.2 \%$ in buying of sodas. The School Health Survey from $2008^{(7)}$ showed that fruit, vegetables and milk are not among the 10 most consumed foods in schools, while soda and sweetened drinks are among the top five beverages consumed in schools.

Nowadays, overweight and obesity are a priority for public health, both around the world and in Mexico. In light of the seriousness of the situation, it is clear that both government and society must act to combat the epidemic of obesity. The problem requires actions and policies that reside outside of the health sector domain.

After a few years of extensive work collecting information, reviewing experiences and engaging in constant discussion with national and international experts and stakeholders, government, industry and academia agreed to put together the National 


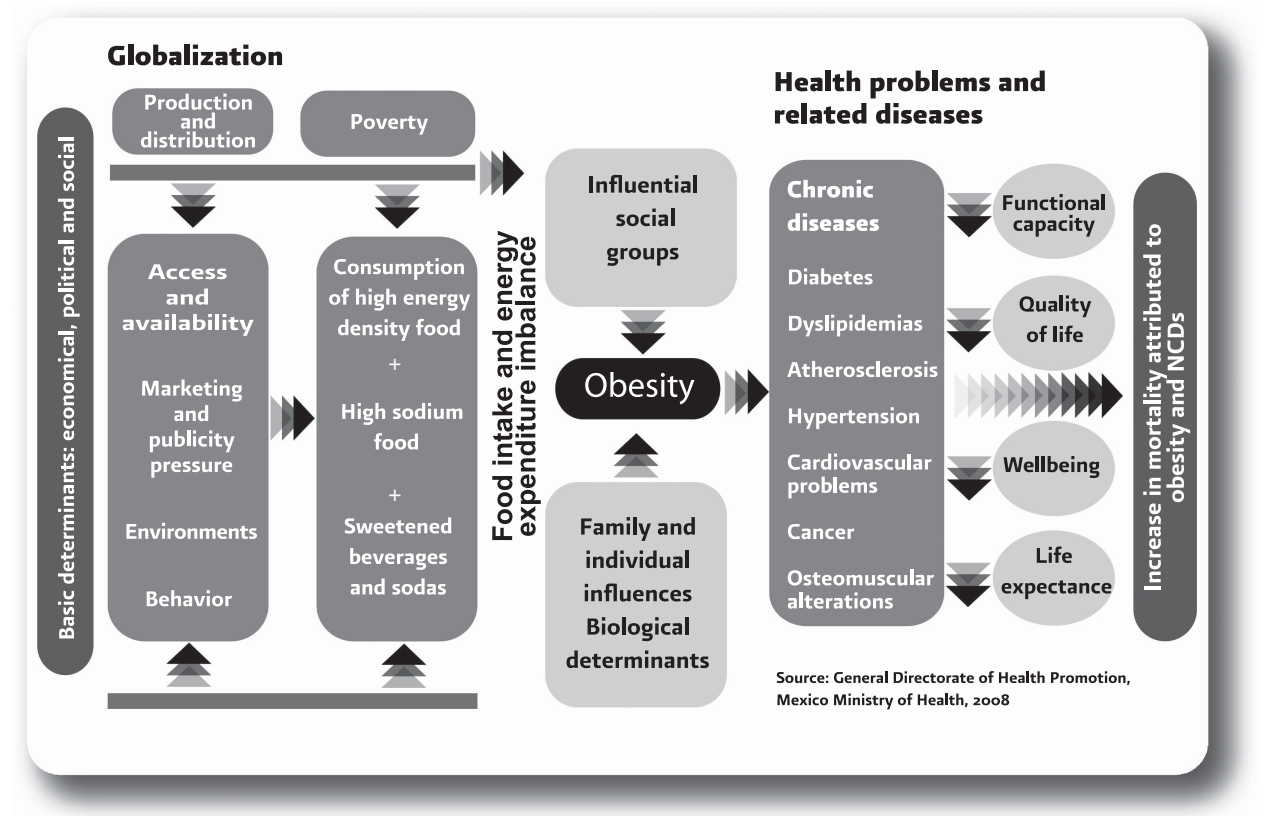

Figure 1. Main determinants of obesity and associated non-communicable chronic diseases (with permission from reference Secretaria de Salud ${ }^{3}$ ).

Agreement for Nutritional Health-Strategy to Control Overweight and Obesity, and work on common goals consistent with the life-course approach for obesity prevention:

1. To decrease the prevalence of obesity and overweight in the 2- to 5-year-old population, as presented in 2006 (ENSANUT 2006).

2. To stop obesity and overweight prevalence growth in the 5- to 19-year-old population.

3. To slow the increase of obesity and overweight prevalence in adults.

Similar policies in other countries, as well as international guidelines and recommendations, show that the solutions for this problem are based on modification of the environments and change of individual habits and conduct related to nutrition and physical activity. This has been established into 10 priority objectives of the National Agreement: ${ }^{5}$

1. Promote physical activity in all settings (school, work, community, recreational).

2. Increase availability, accessibility and consumption of water.

3. Decrease sugar and fat in drinks.

4. Increase consumption of vegetables and fruits, legumes, whole grains and fiber.

5. Improve decision-making capacity through labeling and promotion of health and nutrition literacy.

6. Promote exclusive breastfeeding during the first 6 months of life.

7. Reduce the amount of sugar added in food.

8. Decrease consumption of saturated fats and eliminate trans fats in processed food.

9. Encourage elaboration of smaller servings in restaurants and food outlets, and diminish the portion size of processed food.

10. Limit the amount of sodium added to foods and reduce sodium intake (included because of its importance for chronic diseases prevention, especially hypertension and cardiovascular diseases).
The agreement was signed by 15 government agencies from the fields of health, economics, education, agriculture, labor and social welfare, social development, along with non-governmental organizations, academia and, importantly, the food and beverage industry, which agreed to work together under main principles of this national strategy: common goals, shared responsibility, transparency, accountability, gradual implementation and solidarity.

One of the key aspects of this health policy was agreement among all stakeholders on cross-cutting actions. The Mexican agreement is based on four transverse activities that need to be implemented for each of 10 objectives:

1. Information, education and communication: promoting access to information based on scientific evidence and health education for responsible and informed decision making of the population, including the promotion of healthy lifestyles.

2. Advocacy, co-regulation and regulation: development of healthy public policies across sectors to improve nutrition and physical activity habits in different settings, restoration of public spaces and parks, regulations of publicity and marketing of food and beverages, among other actions.

3. Monitoring and evaluation: Follow-up and evaluation of the actions taken, to ensure their fulfillment.

4. Research: some topics, such as effectiveness of public health policies targeting modification of environments, taxation interventions and health literacy, for example, are not sufficiently explored as strategies for obesity prevention.

One of the best examples of the National Agreement's intersectorial action implementation is in the school setting. Schools are considered an important environment to promote healthy nutrition and regular physical activity. Together, the Ministry of Public Education and the Ministry of Health developed a plan of action in the school context with emphasis on health promotion and education, regular physical activity promotion and availability, and access to healthy food and drinks in schools. To guarantee the offer of healthy foods and beverages in primary and secondary schools, the Guidelines on Nutrition Standards for Foods and Beverages ${ }^{8}$ were developed. They establish nutritional criteria and 
procedures for foods and beverages that are produced, distributed and sold at schools, with an emphasis on the reduction of the caloric value of school snacks. The guidelines apply in both public and private primary and secondary schools of the country. Since the 2010-2011 school year, implementation of the guidelines has been gradual (by school years) to allow a sustained and continuous change, permitting the process of acceptance and adjustment of all actors involved, as well as to allow industry to develop new and modify old products so they can meet the criteria to be sold in schools.

Other example is the arrangement established with the food and beverage industry to limit marketing and advertising of their products to children under the age of 12 . This resulted in the Code of Self-regulation on Advertising of Food and Non-Alcoholic Beverages to Children ${ }^{9}$ that came into force on 19 January 2009. The code respects current national legislation on advertising and marketing to children and youth, as well as recommendations from the World Health Organization. This regulation confirms the commitment of the private sector to contribute to the achievement of the agreement's objectives.

The overall purpose of the National Agreement is to position obesity and overweight as one of the major barriers to national sustainable development, and to issue a call for action of the public and private sectors as well as society, to sum up the actions for obesity and non-communicable chronic diseases prevention. The National Agreement tackles risk factors as well as social and environmental determinants during the life-course. This approach permits the development of an integral, multi stakeholders plan for achieving and maintaining healthy weight and postponing the appearance of related diseases by promoting healthy lifestyles focused on correct diet and physical activity at all stages of life; from pregnancy and early childhood and on into adulthood.

Although there have been great achievements in some areas of implementation, there are still challenges to confront. This year will be critical for the evaluation of the agreement and will mark the way ahead in reinforcement of the existing, and construction of other, national health policies.

\section{CONFLICT OF INTEREST}

The authors declare no conflict of interest.

\section{ACKNOWLEDGEMENTS}

Publication was supported in part by the Government of Aruba, the Obetech Obesity Research Center, the Pan American Health Organization and the Pan American Health and Education Foundation. This paper is derived from the workshop 'Education for childhood obesity prevention: A life-course approach', co-organized by the Panamerican Health Organization (PAHO) and the Panamerican Health and Education Foundation (PAHEF), and held on 14 June 2012 in Aruba, as part of the II PanAmerican Conference on Childhood Obesity (http://www.paco.aw/).

\section{REFERENCES}

1 Organization for Economic Co-Operation and Development. Obesity Update 2012 (cited 27 August 2012). Available from: http://www.oecd.org/els/healthpolicie sanddata/49716427.pdf.

2 Olaiz-Fernandez G, Rivera-Dommarco J, Shamah-Levy T, Rojas R, VillapandoHernandez S, Hernandez-Avila M et al. Encuesta Nacional de Salud y Nutrición 2006. Instituto Nacional de Salud Publica: Cuernavaca, Mexico, 2006.

3 Secretaria de Salud. Bases para una Política de Estado para la Prevención de la Obesidad. Instituto Nacional de Salud Pública: Cuernavaca, Mexico, 2009.

4 Rivera-Dommarco J, Shamah T, Villapando Hernandez S, Gonzalez de Cossio T, Hernandez Prado B, Sepulveda J. Encuesta Nacional de Nutrición 1999. Estado nutricio de niños y mujeres en Mexico. Instituto Nacional de Salud Publica: Cuernavaca, Mexico, 2001. Available from: http://www.nutricionenmexico.com/ encuestas/ENN-99.pdf.

5 Secretaría de Salud, Dirección General de Promoción de la Salud. Acuerdo Nacional para la Salud Alimentaria: Estrategia contra el sobrepeso y la obesidad. Mexico. Dirección General de Promoción de la Salud, 2nd Edition, 2010.

6 Rivera-Dommarco J, Shamah T, Villapando S, Cuevas L, Mundo V, Morales-Rual C. El estado nutricional de la población de México: cambios en la magnitud, distribución y tendencias de la mala nutrición de 1988 a 2006. Salud Pública, Nutrición y Pobreza: Política pública basada en evidencia, Mexico, Banco MundialSEDESOL, 2008, pp 1-22.

7 Instituto Nacional de Salud Pública. Encuesta Nacional de Salud de Escolares. Mexico, 2008 (updated 18 July 2012; cited 28 August 2012). Available from: http:// www.insp.mx/images/stories/Produccion/pdf/101202_ense.pdf.

8 Secretaría de Educación Pública, Secretaría de Salud. Lineamientos Generales para el expendio o distribución de alimentos y bebidas en los establecimientos del consumo escolar de los planteles de educación básica, Mexico, 2010 (cited 31 August 2012). Available from: http://promocion.salud.gob.mx/dgps/descargas1/ programas/escuela_salud/Lineamientos_alimentacion_escuelas.pdf.

9 Consejo Nacional de Autorregulación y Ética Publicitaria. Código de Autorregulación de Publicidad de Alimentos y Bebidas no alcohólicas dirigida al público infantil. Mexico, 2008 (cited 2 September 2012). Available from: http://www. promocion.salud.gob.mx/dgps/descargas1/programas/codigo_pabi.pdf. 